\title{
A NEW PERSPECTIVE FOR THE INTEGRATION OF SKILLS TO READING
}

\author{
Meltem Huri Baturay-Nurgun Akar
}

\begin{abstract}
A striking debate has arisen shortly on the discrimination of teaching language skills discretely or teaching them co-operatively. Integration of the skills are The concern of this study is to identify and exhibit the differences between teaching reading in a discrete skill program, in which reading is taught separately and traditionally, and in an integrated skills program, in which reading is taught in an integrated manner. Differing from the previous studies on the same topic in the field, integration has been assessed from different perspectives, which has given rise to a new categorization of skills: grammatical integration, functional integration, and thematic integration. A few course books have been surveyed to pinpoint to what extent integration takes place in them. And this new model of evaluation is underpinned throughout the study.
\end{abstract}

Key Words: Integration, Skills, Reading, Teaching English, Language Teaching

\section{DİĞER BECERiLERIN OKUMA BECERISiNE ENTEGRASYONUNDA YENi BiR YAKLAŞIM}

$$
\ddot{O}_{z e t}
$$

Son zamanlarda dil becerilerinin birlik içerisinde veya ayrı ayrı öğretilmesinin ayrımı üzerinde çarpıcı tartışmalar yapılmaktadır. Dil becerilerinin öğretilmesi kapsamlı ve karmaşık bir konudur. Bu çalışmanın amacı okuma becerisinin tek başına yani geleneksel bir biçimde öğretildiği bir program ile okuma becerisinin diğer becerilerle entegre edilerek öğretildiği bir program arasındaki farklılıkları teşhis etmek ve gözler önüne sermektir. Bu konuda yapılmış daha önceki çalışmalardan farklı olarak, becerilerin entegre edilmesi değişik bir bakış açısından değerlendirilmiş ve bu da becerilerin entegre edilmesinde eksik olan yeni bir kategorinin ortaya çıkmasına yol açmıştır. Ve çalışma boyunca bu yeni değerlendirme biçimi desteklenmiştir.

Anahtar Sözcükler: Entegrasyon, Beceriler, Okuma Becerisi, Ingilizce Öğretimi, Dil Öğretimi 


\section{Introduction}

Mainly, there is grammatical integration among the skills and activities appearing throughout the unit. Except in the Listening and Speaking and Everyday English sections, the functional integration does not obviously take place anywhere. Finally, thematic integration exists with two different themes in a few activities.

There have been many studies carried out on the problem of teaching reading in the most efficient way. Some of the problems that reading teachers encounter are summarized by King (1968) as follows: Students are becoming more and more dependent on the teacher while dealing with fewer and fewer activities in the classroom; another problem is that teachers are doing most of the work for their students, as a result of which students' language skills and linguistic competence cannot develop satisfactorily. Consequently, students are bored and lose interest in reading texts, which are solely followed by comprehension questions, create a nonauthentic type of session. Concerning this Yllmazer states that

"Students tend to get bored when they are just handed a text and told to read and answer the questions that follow. As they do not have enough motivation, they are not actively engaged in the task they are given. Furthermore, when the comprehension questions are done and checked, the text is left out." (1997, p.59).

What is mentioned here is a typical, traditional teaching activity of reading. However, when teachers use other kinds of skills such as listening, writing and speaking together with reading, it becomes more beneficial and authentic for the students because in real life, when we communicate, one skill often is not performed without any other.

Using an integrated skills approach enables the students to develop their ability in the use of two or more of the four skills within real contexts and in a communicative framework. Hersan Z.M. points out that

"Nowadays, communication is the major aim for learning a foreign language. In daily life, these skills are seen in integration, for example, after reading a letter, usually an answer to this letter is written. So in the classroom the activities should be taught in integration in order to arrive at ease in communication." (1998, p. 22). 
Similarly, Sanchez (2000) emphasizes that practicing receptive and productive skills in isolation in the past have made the transition from 'in-classroom' to 'outof-classroom' practices 'artificial'. In a way, by using the other skills with reading, we are following a communicative approach to language teaching which is based on the belief that good learning means not only reading or writing but also speaking and listening.

To summarize, four language skills are rarely used alone in everyday life. The writers, therefore, aim to put them together in integration for the sake of teaching reading which is generally neglected in textbooks, course books and/or reading classes and hope to avoid the traditional classroom models of reading instruction whereby teachers dominate classroom talk and students respond during text-driven question-and-answer sessions. However, the writers believe that the integration of skills is not the only type of integration teachers should aim at. They believe that there exist three areas, which should be integrated with each other during textbook writing and while developing other materials. These areas can be entitled as

a) grammatical integration,

b) functional integration,

c) thematic integration.

It is suggested that all three types of integration should be put together as far as possible.

\section{The Difference Between Reinforcement and Integration of Skills}

Generally course books cover reinforced reading activities, and they are assumed to be integrated. However, a reinforced reading activity is not different from a traditional reading activity. It is an activity followed by comprehension questions or other activities sometimes concerning even writing, listening and speaking. If the aim here is to have a communicative setting, the skill integration should be formed as communicatively as in real life; that is, we should keep in mind as a guide the way in which they are normally brought together in real life. It is generally observed that in an authentic setting, the use of any skill may lead on very naturally to the use of another. 


\section{Teaching Reading by Integrating It with Other Skills}

When several ELT textbooks are surveyed, the most common pattern emerging as reading activities is that of a reading text followed by comprehension questions, and some vocabulary, true/false questions, possibly a few discussion questions. These activities are set up in the following steps:

1. Teacher assigns a reading text,

2. The students read the assigned text that their teacher has chosen,

3. The students answer the comprehension or true/false questions which are already given below the text,

4. The teacher checks if the students have answered the questions correctly,

5. Some study on vocabulary and grammar is done.

If a teacher follows, in his/her lessons, the set of rules mentioned above, students are likely to get bored since such questions are not authentic; they decrease motivation, and enthusiasm. It is a fact that this way of teaching reading is not interesting for students.

According to Grellet, (1981) reading comprehension and other skills should be presented together. She states

"There are few cases in real life when we do not talk or write about what we have read or when we do not relate what we have read to something we might have heard. It's, therefore, important to link the different skills through reading activities."'(1981, p. 8).

For integration of skills, Kyriacou (1991) points out that during the integration of skills, the notion of "smoothness" should be provided. That is, activities should be chosen so correctly that the transition between activities should be smooth.

According to Abbott, Wingard and Mckeating (1981) there are psychological and practical reasons for the integration of writing with other skills, and so it is in our case: there are plausible reasons for the integration of reading with other skills. These are as follows:

1. When analyzed, there is a large overlap among the component skills of the four skills: listening, speaking, reading and writing. Although there are differences, 
many elements are in common. Therefore, to teach these four skills in close association facilitates learning.

2. In real-life communication, there is a frequent alternation between receptive and productive activities.

3. People have differences in their ability to learn through the ear, the eye and muscular movement. Integration makes use of all these abilities so that everyone can learn something from this process.

4. If something is taken in through more than one channel, it is more likely to be learned well. Practices in these skills can be mutually reinforcing; that is, the channels can reinforce each other.

5. Students even of the same age, sex and cultural background are often not interested in the same thing (1981, p. 93). Similarly, their interests over the skills activities may have differences.

The facts stated above require the use of skills together. Harmer (1983) has pointed out that one of the teacher's responsibilities is that the students should practise all the skills. He finds separating skills ridiculous and he adds that

"Someone who listens to a lecture may take notes and then write a report of the lecture. The same person might also describe the lecture to his friends or colleagues and follow it up by reading an article that the lecturer suggested." (1983, p. 47)

Byrne (1990) confirms this with an example. For instance, one sees an ad in the newspaper (for a job, holiday or device); talks about it to someone else or rings him up or writes a letter or chats on the computer. These kinds of activities could follow and provide a natural setting for language teaching/learning. Similarly, Cunningsworth states that

"In the actual language use, one skill is rarely used in isolation... Numerous communicative situations in real life involve integrating two or more of the four skills. The user of the language exercises his abilities in two or more skills, either simultaneously or in close succession." (1984, p.46). 
Again according to Finocchiaro (1973) a good teacher recognizes the importance of integrating discrete language skills in the communicative situations, which simulate or duplicate the real life situations in which students will need to use the foreign language. When reading is practiced through other skills 'integratedly' as in real life, it will become more interesting, motivating and effective for the students.

Temperley defines the reason why reading is linked with listening as "students learn to segment an oral message and then they try to recognize these groupings in graphic form". $(1978,213)$. Dubin and Olshtain support Temperley's ideas by stating "Listening shares a number of features with reading since the two are interpretative skills which play an important role in communication..." (1987, 100-101). The use of listening with other skills not only enhances the amount of real comprehension and eliminates the problems about listening materials, but also brings a communicative touch to the process. Peck states that "Listening comprehension, together with reading, offers one of the most powerful means of extending students' stock of language items with which they can later express themselves in speech or writing." (1988, p.187).

One of the tenets of the whole language movement is that reading and writing should be taught at the same time. This is also widely accepted in cognitive psychology. Research has supported the view that developments in reading and writing are closely connected (Tierney, R.J. \& Pearson, P.D., 1983; Tierney, R.J., Soter., O'Flahavan, J.O, \& McGinley, W.,1984; Tierney, R.J., \& Shanahan, J., 1991). Recently, course books and textbooks have shown a shift by leaving a skill-based reading approach to reading and applying reading-writing components. Jeanette and Moseley state it in the preface of their book as

"...today the idea of integrating writing and reading instruction is gaining increased acceptance because research has indicated its theoretical validity and teachers have discovered its pedagogical effectiveness. Instructors of both writing and reading have in many cases already begun to offer integrated instruction that allows students to view writing and reading in the same rhetorical context." (1985, p.vii).

Writing has generally been an uninteresting, dull experience for students and causes reluctance. In order to make writing more interesting and enjoyable for stu- 
dents, it has to be integrated into the other activities; thus, the psychological barrier that has grown up around it can be removed.

As for speaking-reading skills integration, students should frequently be provided with the same opportunities to give in English the gist of what they have read. The reading material may serve as a basis for oral presentations; some may be dramatized in role-plays and some may provide a setting for discussions and debates on the same theme and so on.

\section{A Differing Category/Type of Integration}

In this study, a new categorization for the integration of skills is being proposed. This category involves viewing integration from the angle of three areas simultaneously; namely, grammar, language functions and topics/themes. The writers prefer to separate the concept of integration into two as below, and will handle course book evaluations mainly from this perspective.

Table 1 Types of Integration

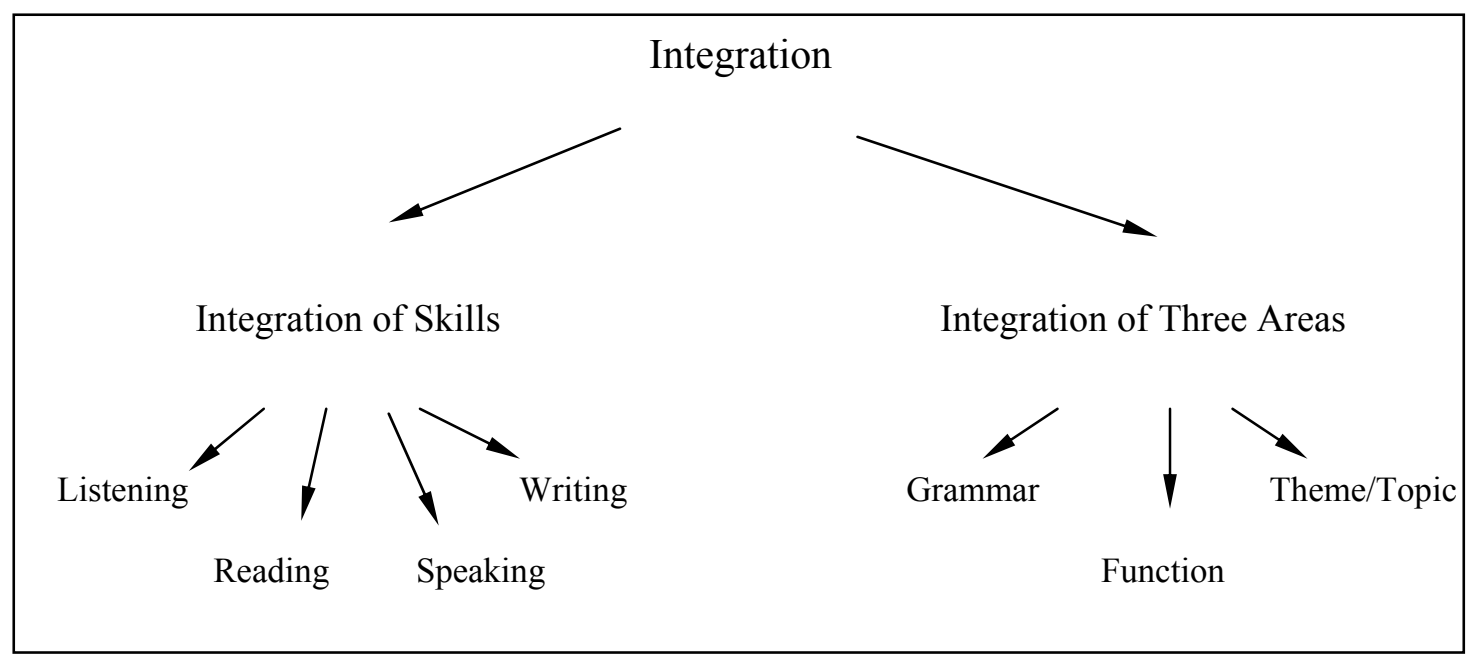




\section{The Method}

Although skill integration is an innovative approach, which is highly appreciated by many course book writers, it does not appear to be explicitly examined and a categorization is lacking. Not only the scarcity of the materials concerning the area but also the way which the subject being examined have given great trouble to the writers because it is not clear in what aspect a course book is thought to be integrated or not. The writers, therefore, argue that increasing the rigor of observations of skill integration/separation opens the way for their more systematic explanation.

Up to now, in previous chapters, it has been emphasized that skills integration, especially the integration of reading to other skills is inevitable if a communicative way of teaching is applied. However, it should not be limited to skills integration only in a thematic way. After running through other course books, the writers have hypothesized a skills integration model roughly falling into three categories as grammatical, functional and thematic/topical.

\section{Grammatical Integration}

Most of the course books apply this type of integration. There is no topical/thematic unity among the skills activities, but they reinforce the same grammatical item. Therefore, one/a unit of the course book is completely centred on items such as tenses, articles, adverbial forms and so on with its skills activities. This type of integrated unit in a book can be confused with a wholly grammarbased unit. The difference between a wholly grammatical unit and a grammatically integrated unit is that while the former one ignores the communicative value of language, the second one recognizes it by using different skills communicatively, focusing on a grammatical item. That is, the course book is still communicative with its follow-up activities although it gives importance to grammar a great deal. Skills activities might be presented in different topics and settings but focusing on only one grammatical item and without logical links among them. There are no logical links among them because if there were, it means that there would also be a topical/thematic integration taking place.

\section{Functional Integration}

It focuses on gathering and using skills in an organization around one social function of language. Therefore, it is concerned with elements such as invitations, 
apologies, suggestions, refuses and so forth. It helps the student to recognize that he has a real purpose for speaking. A functional element or expression is given in all skills activities but there is not topical or thematic unity among the skills. Sometimes both can operate or sometimes, the same grammatical item is presented besides the same functional element in skills activities.

\section{Thematic/Topical Integration}

We all know what a topic is; it is simply what is being talked or written about. In this type of integration, skills are practiced in conjunction with each other around a topic in the way they are integrated in real life. If there is a context, and skills activities are not isolated from this context, there thought to be a topical unity among activities. They follow each other meaningfully; there seems to be a storytaking place with logical connections. Whenever the writers have examined the course books for the integration of skills, this is the only type of integration the course books seem to cover under the title of "Integration of Four Skills".

\section{Findings}

The writers have randomly chosen the coursebooks which are in common studied at school and college settings in Turkey. They analyzed True Colors II, Headway Pre-Intermediate, Language In Use Pre-Intermediate, Blue Print II and Life Lines Pre-Intermediate from the given perspective. And while evaluating the course books, the writers have regarded the course book units as integrated even though not four but only two or three of the skills were integrated. (see table 2)

\section{True Colors II (Unit 9)}

In True Colors, although reading is not integrated with other skills thematically but grammatically and functionally, there is thematic integration among PhotoStory, the dialogue and the listening part to a certain degree. Correspondingly, there are grammatical and functional integration among the sections involving all the skills.

\section{Headway Pre-Intermediate (Unit 14)}

Considering all, this is an integrated unit. On the other hand, with respect to reading, it does not possess either functional or thematic integration but only grammatical one by means of a few sample sentences involving grammatical items. 


\section{Language in Use Pre-Intermediate (Unit 17)}

In short, the unit taken from Language In Use Pre-Intermediate course book, exhibits all kinds of integration. The functions and structures overlapping each other are used in every part of the unit, which gives way to integrations. Thematic integration, only seen in one activity, combines speaking to reading. Reading is grammatically, functionally and thematically integrated with the other skills activities.

\section{Blueprint Two (Unit 11)}

As regards this unit it can be advocated that all types of integrations prevail in the units of the course book. Although, the focus is on grammatical and functional integration, there is also thematic integration. Reading is presented briefly and it is only thematically integrated.

\section{Lifelines Pre-Intermediate (Unit 1)}

It is obvious that the unit has grammatical integration. In connection with it, there is functional integration throughout the unit. Additionally, there is thematic integration to some degree in the Reading Section. As a consequence, Lifelines covers all kinds of integration in the chosen unit.

Table 2 Analysis Results of the Course Books

\begin{tabular}{|c|c|c|c|}
\hline $\begin{array}{c}\text { Course } \\
\text { Books }\end{array}$ & $\begin{array}{c}\text { Grammatical } \\
\text { Integration }\end{array}$ & $\begin{array}{c}\text { Functional Inte- } \\
\text { gration }\end{array}$ & $\begin{array}{c}\text { Thematic/Topical } \\
\text { Integration }\end{array}$ \\
\hline True Colors & Yes & Yes & Partial \\
\hline Headway & Yes & Partial & Partial \\
\hline Language in Use & Yes & Yes & Yes \\
\hline Blueprint & Partial & Partial & Yes \\
\hline Lifelines & Yes & Yes & Partial \\
\hline
\end{tabular}




\section{Conclusion}

The purpose of this study was to suggest that teaching reading more 'integratedly' via the other skills would make the students more successful and more eager to learn than they can be if the reading skill is taught discretely in other words traditionally. Generally, what an English teacher does in practice is to have his/her students read a text without any pre-reading activity and answer comprehension questions. However, it not only makes the students bored during lecture but also causes them to refrain from reading because of its difficulty. With regard to teaching reading, Willis, J. (1991) states that

"In real life when we pick something up to read, we usually know roughly why it was written and what it is going to be about. We rarely read anything in a 'vacuum', i.e. knowing nothing whatsoever about the subject. Reading passages in language textbooks are taken out of their normal contexts, so we have fewer clues as to what they might be about; the task of reading with understanding is, therefore, more difficult...” (p, 150).

The reading skill may be communicatively and efficiently exercised through one or more of the other skills in order to enhance the motivation of the students and lower the hindrance of the control of the class during the lesson time. In accordance with these beliefs, the writers have chosen to focus on the differences between traditional reading sessions and integrated ones, the skill of reading and reading activities in books and suggested an ideal more 'perfect' sample unit with all types of skills and suggested integration types.

\section{References:}

Abbott, G., Wingard, P., \& Mckeating, D. 1981. The teaching of English as an international language, London: Collins.

Byrne, D. 1990. Teaching writing skills, London: Longman.

Canavan, P., King, J., and Louise, M., (1968). Developing reading skills, Boston: Allyn \& Bacon.

Casaneve, C.P. 1988. Adding communication to the ESL reading class. TESOL Newsletter, Vol: XXII, 22-23.

Cunningsworth, A. 1984. Evaluating and selecting EFL teaching materials, London: Heinemann. 
Dubin, F. \& Olshtain, E. 1987. Course design: developing programs and materials for language learning, Cambridge: CUP.

Finocchiaro, M. \& Bonomo, M. 1973. The foreign language learner, NewYork: Regents Publishing Comp Inc.

Grellet, F. 1981. Developing reading skills, Cambridge: CUP.

Harmer, J. 2001. The practice of English language teaching, Essex: Longman.

Hersan, M. Z . 1998. The integration of reading and writing through pair and group work. A Master's Thesis, Hacettepe University, Ankara.

Hopwood, T. \& Rushton, L. 1990. Heinemann integrated skills, Oxford: Heinemann.

Jeanette, H. \& Moseley, A. 1985. Contexts writing and reading, Boston: Houghton Mifflin Company.

Kyriacou, C. 1991. Essential teaching skills, Oxford: Basil Blackwell Ltd.

Peck, A. 1988. Language teachers at work, Cambridge: Prentice Hall.

Sanchez, M. A.A. 2000. An approach to the integration of skills in English teaching. Didactica (Lengua y Literatura), 12,21-41.

Temperley, M. S. \& Rivers, W. M. 1978. A practical guide to the teaching of English as a second or foreign language, Oxford: OUP.

Tierney, R.J., \& Pearson P.D. 1983. Toward a composing model of reading. Language Arts, $60,569-580$

Tierney, R.J., Soter, A., O’Flahavan, J.O. \& McGinley, W. 1984. The effects of reading and writing upon thinking critically. Reading Research Quarterly, 24, 134-173

Tierney, R.J., \& Shanahan, J. 1991. Research on the Reading-Writing Relationship: Interactions, Transactions and Outcomes. In R. Barr, M. Kamil, P. Mosenthal, \& P.D. Pearson (Eds.), Handbook of Reading Research, Vol. 2, 609-640.

Willis, J. 1981. Teaching English through English, New York: Longman.

Yılmazer, A. 1997. Making a Reading Lesson More Challenging: Is it Mission Impossible?, In Perspectives in English Language Teaching, The 4th Metu ELT Convention, Ankara: Metu. 